$Q C=$ 100 45753 $10.710-3$ 1972

U.S. PARTMENT OF
COMMERCE
National
Bureau
of
Standards OF
COMMERCE
National
Bureau
of
Standards OF
COMMERCE
National
Bureau
of
Standards OF
COMMERCE
National
Bureau
of
Standards OF
COMMERCE
National
Bureau
of
Standards OF
COMMERCE
National
Bureau
of
Standards

\title{
BUILDING
} RESEARCH TRANSLATION New Regulation On Ventilation of Dwellings, Fixed Heating Facilities, And Flues 


\section{NATIONAL BUREAU OF STANDARDS}

The National Bureau of Standards ${ }^{1}$ was established by an act of Congress March 3, 1901. The Bureau's overall goal is to strengthen and advance the Nation's science and technology and facilitate their effective application for public benefit. To this end, the Bureau conducts research and provides: (1) a basis for the Nation's physical measurement system, (2) scientific and technological services for industry and government, (3) a technical basis for equity in trade, and (4) technical services to promote public safety. The Bureau consists of the Institute for Basic Standards, the Institute for Materials Research, the Institute for Applied Technology, the Center for Computer Sciences and Technology, and the Office for Information Programs.

THE INSTITUTE FOR BASIC STANDARDS provides the central basis within the United States of a complete and consistent system of physical measurement; coordinates that system with measurement sy'stems of other nations: and furnishes essential services leading to accurate and uniform physical measurements throughout the Nation's scientific community, industry, and commerce. The Institute consists of a Center for Radiation Research, an Office of Measurement Services and the following divisions:

Applied Mathematics-Electricity-Heat-Mechanics-Optical Physics-Linac Radiation ${ }^{2}$ - Nuclear Radiation'- Applied Radiation ${ }^{2}$ - Quantum Electronics ${ }^{3}$ Electromagnetics ${ }^{3}$ - Time and Frequency ${ }^{3}$ - Laboratory Astrophysics ${ }^{3}$ - Cryogenics $^{3}$.

THE INSTITUTE FOR MATERIALS RESEARCH conducts materials research leading to improved methods of measurement, standards, and data on the properties of well-characterized materials needed by industry. commerce, educational institutions, and Government; provides advisory and research services to other Government agencies; and develops, produces, and distributes standard reference materials. The Institute consists of the Office of Standard Reference Materials and the following divisions:

Analytical Chemistry-Polymers-Metallurgy-Inorganic Materials-Reactor Radiation-Physical Chemistry.

THE INSTITUTE FOR APPLIED TECHNOLOGY provides technical services to promote the use of available technology and to facilitate technological innovation in industry and Government; cooperates with public and private organizations leading to the development of technological standards (including mandatory safety standards), codes and methods of test; and provides technical advice and services to Government agencies upon request. The Institute also monitors NBS engineering standards activities and provides liaison between NBS and national and international engineering standards bodies. The lnstitute consists of the following divisions and offices:

Engineering Standards Services-Weights and Measures-Invention and Innovation-Product Evaluation Technology-Building Research-Electronic Technology-Technical Analysis-Measurement Engineering-Office of Fire Programs.

THE CENTER FOR COMPUTER SCIENCES AND TECHNOLOGY conducts research and provides technical services designed to aid Government agencies in improving cost effectiveness in the conduct of their programs through the selection, acquisition, and effective utilization of automatic data processing equipment; and serves as the principal focus within the executive branch for the development of Federal standards for automatic data processing equipment, techniques, and computer languages. The Center consists of the following offices and divisions:

Information Processing Standards-Computer Information-Computer Services - Systems Development--Information Processing Technology.

THE OFFICE FOR INFORMATION PROGRAMS promotes optimum dissemination and accessibility of scientific information generated within NBS and other agencies of the Federal Government; promotes the developinent of the National Standard Reference Data System and a system of information analysis centers dealing with the broader aspects of the National Mcasurement System; provides appropriate services to ensure that the NBS staff has optimum accessibility to the scientific information of the world. and directs the public information activities of the Bureau. The Oftice consists of the following organizational units:

Office of Standard Reference Data-Office of Technical Information and Publications--Library-Office of International Relations. 1 Headquarters and Laboratories at Gaithershurg, Maryland, unless otherwise noted: mailing address Washing-
ton, D.C. 20234 .

Part of the Center for Radiation Research.

socated at Boulder, Colorado 80302. 


\title{
BUILDING RESEARCH TRANSLATION New Regulation on Ventilation of Dwellings, Fixed Heating Facilities, and Flues
}

\author{
A. Chalandon, M. Schumann, and \\ P. Dechartre
}

Centre Scientifique et Technique du Bâtiment

Paris, France

Translated by the Joint Publication

Research Service,

U.S. Department of Commerce,

Washington, D.C. 20234
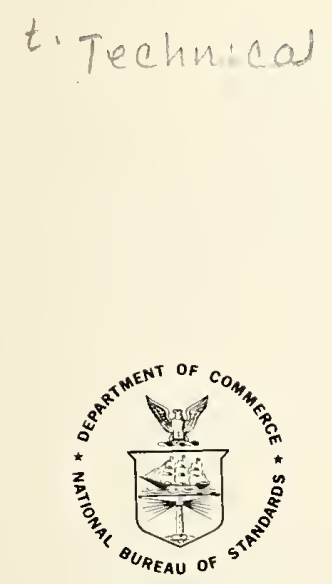

U.S. DEPARTMENT OF COMMERCE, Peter G. Peterson, Secretary

U. 5 . NATIONAL BUREAU OF STANDARDS, Lawrence M. Kushner, Acting Director

Issued May 1972 


\section{National Bureau of Standards Technical Note 710-3}

Nat. Bur. Stand. (U.S.), Tech. Note 710-3, 46 pages (May 1972)

CODEN: NBTNAE

Issued May 1972

For sale by the Superintendent of Documents, U.S. Government Printing Office, Washington, D.C. 20402 (Order by SD Catalog No. C13.46:710-3). Price 50 cents. 


\section{FOREWORD}

The United States/French Cooperative Program on Building Technology entails an exchange of personnel between the National Bureau of Standards (Building Research Division) and the Centre Scientifique et Technique du Bâtiment (CSTB) of France. The program also involves the exchange of information between the two research organizations.

It is felt that some of the documented information can be usefully shared with the U.S. building industry; and, therefore, certain papers were selected for reproduction in media on sale to the public by the Government Printing Office. It should be understood that the CSTB documents made public through such media as this TECHNICAL NOTE do not necessarily represent the views of the National Bureau of Standards on either policy or technical levels.

At the same time, building researchers at the National Bureau of Standards consider it a public service to share with the U.S. building industry certain insights into French building technology.

\footnotetext{
Sanes K. Whoter

JAMES R. WRIGHT

Chief, Building Research Division

Institute for Applied Technology

National Bureau of Standards
} 



\section{NEW REGULATION ON VENTILATION OF DWELLINGS, FIXED HEATING FACILITIES, AND FLUES I/}

prepared by

A. Chalandon, M. Schumann, P. Dechartre

Following studies on the ventilation of dwellings, the results of which have been published in CSTB "Cahiers," the CSTB has proposed certain changes in the regulations governing the ventilation of dwellings. At the same time, in the light of recent statistics on secondary emergency and relief heating, changes in the regulations governing fixed heating installations and flues were proposed. These proposals led to a new revised text of the French regulations, which we publish below, together with a new chapter on "ventilation" from the CSTB Technical Report.

Key words: Air infiltration and extraction; airtightness; discomfort index; duct system, collective and individual branch; flow rates; noise; pressure-loss-depression; thermal convection; ventilation.

1/This paper is translated from the French original and is published under the Building Research Division/ Centre Scientifique et Technique du Bâtiment information exchange program. 


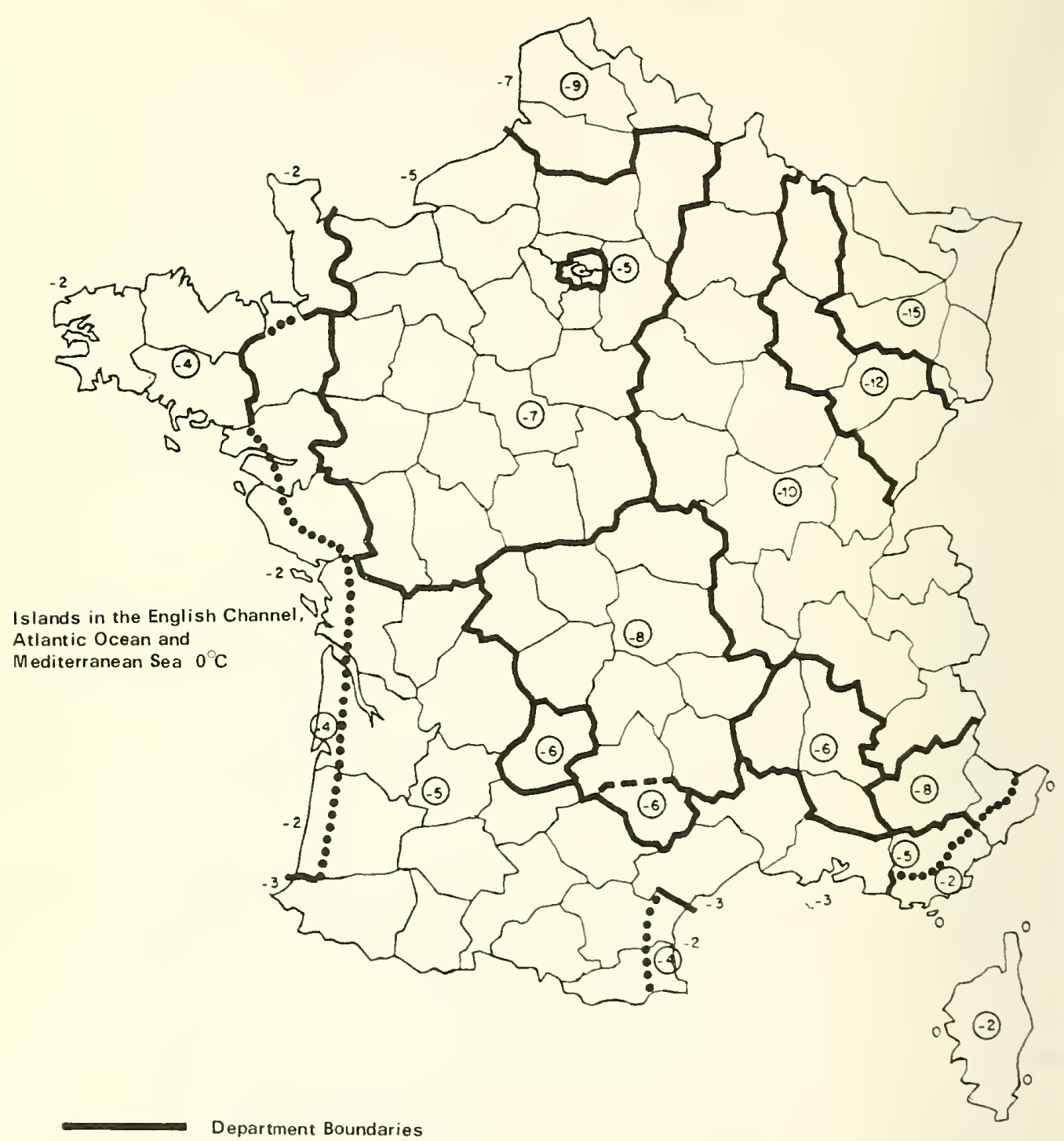

Department Boundaries

Distance from the $\mathrm{sea}=25 \mathrm{~km}$

$=-\infty$ Mountain ridges south of Aveyron River

Noncircled values shown in the seas and oceans are for a distance inland of less than 3 kilometers from the sea. 
Title 8

VENTILATION

\section{Introduction}

This Technical Report was prepared by the Scientific and Technical Center for Building Construction, and presents design solutions for use in complying with the provisions of the 30 April 1969 decree 2 / on ventilation of dwellings.

The purpose of this document is to provide engineering and construction personnel with design (standard) solutions that comply with the provisions of the decree of 30 April 1969 on ventilation of dwellings. The number(s) of the pertinent article(s) of the decree are listed in the chapter headings of this document.

The design solutions presented are not the only possible solutions. They were retained because they appeared reasonable given the present state of construction techniques in France. The rationale for these solutions may be found in studies published in CSTB "Cahiers" No. 478 (issue 59), No. 542 (issue 65), No. 550 (issue 66), No. 590 (issue 70), No. 720 (issue 83), and No. 835 (issue 96). The number(s) of the relevant "Cahier(s)" which may be consulted for this rationale are indicated at the beginning of each paragraph in this document. 
CHAPTER 1: TYPICAL DESIGN FLOW RATES AND TYPICAL DESIGN SOLUTIONS RELEVANT TO CERTAIN GENERAL PROVISIONS (Articles 1, 2 and 3 of the Decree)

\subsection{Typical Flow Rates}

CSTB "Cahier" No. 542, issue 65, outlines the rationale for this selection of the design flow rates proposed in the paragraphs that follow.

The recommended design solutions presented in this document are based on consideration of air-supply and air-exhaust flow rates that are themselves defined. These are the typical flow rates.

Verification of these rates during the acceptance inspection of a building and its equipment is a valid procedure only in the case of mechanical ventilation systems and within those tolerances prescribed in Chapter 3, paragraph 3.11.

In the case of natural ventilation systems, the only verification possible is whether or not the pressure losses or cross sections indicated in Chapters 2 and 4 are being complied with. These pressure losses and cross sections have been calculated so that in winter time, design flow rates may be obtained under average thermal-convection and wind-pressure conditions. Consequently, these flow rates are not obtained at all moments with a natural ventilation system. 
1.11 Typical Design Flow Rates for Air Outlets

The following values were retained for the flow rates at the airsupply outlet:

\section{Kitchen}

in a dwelling with less than three main rooms. . . 45-90 $\mathrm{m}^{3} / \mathrm{h}$ in a dwelling with three or more rooms . . . . . 60-130 $\mathrm{m}^{3} / \mathrm{h}$ Bathrooms or showers

designed for installation of gas appliances. . . . $60 \mathrm{~m}^{3} / \mathrm{h}$ also used as a clothes-drying room . . . . . 30-60 $\mathrm{m}^{3} / \mathrm{h}$ other cases................. $30 \mathrm{~m}^{3} / \mathrm{h}$ Toilet. . . . . . . . . . . . . . $30 \mathrm{~m}^{3} / \mathrm{h}$ Clothes-drying room serviced by the dwelling's general ventilating system

normal-size room ............ . . 0-30 $\mathrm{m}^{3} / \mathrm{h}$ large-size room (20 meters or more of clothesline) . $0-60 \mathrm{~m}^{3} / \mathrm{h}$ Whenever the dwelling does not contain its own drying room-closet, it is then assumed that the bathroom serves as such. Any lavatory having a toilet is likened to a bathroom or shower room.

Two values are shown for some rooms. This is because the accepted design solution assumes that the opening of the air outlet can be manually adjusted. The two values indicated represent the two extreme terminal positions of this adjustment. In this way, the flow rate can be increased in the kitchen when meals are being prepared, and in the drying room (or bathroom serving as a drying room) when clothes are being dried, while preventing any inordinate increase in heat loss by air change the rest of the time. 
The accepted value for the air-inlet flow rate within a main room is one air change per hour.

However, for those special cases where it is desired to adopt standard values, we recommend the following rates:

--standard-size main room (up to $18 \mathrm{~m}^{2}$ ): $30 \mathrm{~m}^{3} / \mathrm{h}$

--large-size main room (more than $18 \mathrm{~m}^{2}$ ): $60 \mathrm{~m}^{3} / \mathrm{hr}$

In heating or air-conditioning calculations, the flow rate values shown above shall be considered as those for air at $20^{\circ} \mathrm{C}$.

1.2 Iocation of an Air Outlet in a Kitchen. Installation of a Range Hood.

It is recommended that the air outlet be placed above that part of the kitchen designed to hold the range (cooking appliances). This arrangement has the particular advantage of permitting a range hood to be installed.

A range hood is especially worthwhile when thermal convection is weak because of the climate (Mediterranean and Atlantic areas) or because of the limited height of the stacks or chimneys (single-family houses).

With an efficient range hood the maximum air-outlet flow rate in the kitchen can be brought from 120 down to $90 \mathrm{~m}^{3} / \mathrm{h}$ or from 90 down to $75 \mathrm{~m}^{3} / \mathrm{h}$.

\subsection{Airtightness of Doors and Windows.}

The values used in this paragraph are taken from the Joint Instructions of the European Union for Approved Building Techniques published in CSTB "Cahier" No. 622 (issue 73) and "Cahier" No. 855 (issue 98). 
To avoid air infiltration--which has the disadvantage of creating undesirable drafts of cold air against which the precautions described in Chapter 5 are not normally taken--all outside doors and windows should be well-fitted and air-tight, especially in an exposed site. It is recommended that in such a site, the permeability of the operable parts and of the movable-louvers of the shutters (roller blinds) not exceed $12 \mathrm{~m}^{3}$ per hour per square meter of openings for a pressure difference of $100 \mathrm{~Pa}^{\frac{3}{}}$. See paragraph 2.2 for the definition of an exposed site.

Air infiltrating through doors that open into apartment building hallways, vestibules, etc. can cause odors to pass from one apartment into another or disturb the ventilation flow in a given apartment. Consequently, to avoid such air infiltration the permeability of these doors must be limited. A permeability of the order of $12 \mathrm{~m}^{3} / \mathrm{h}$ for a pressure difference of $100 \mathrm{~Pa}$ seems to be an appropriate maximum.

CHAPTER 2: DESIGN SOLUTIONS FOR THE PERMANENT AND GENERAL VENTILATION OF A DWELLING WITH AIR BEING EXHAUSTED BY THERMAL CONVECTION (Articles 4 and 5 of the Decree)

\subsection{Air Outlet}

CSTB "Cahier" No. 542 (issue 65) outlines the rationale for the recommended design solutions described in the following paragraphs. It also contains the computations that produced the pressure-loss and crosssection values used in these solutions.

$3 / \mathrm{Pa}=$ Pascal, Newton $/ \mathrm{m}^{2}$

$1 \mathrm{~Pa}=0.004$ inches water gauge pressure 
Article 4 of the Decree provides for the discharge of foul air by stacks or ducts connecting the service rooms (kitchen, bathroom, toilet) with the outside atmosphere. These air outlets have three main parts: the opening for the air outlet in the room, stack or duct, and the vent on the roof.

\subsection{Opening for the Air Outlet in the Room}

For the individual flue or duct, in which the thermal draft gradient with respect to different floor levels is nearly counterbalanced by the pressure loss within the flue or duct due to flow, the cross section of the air-outlet openings may be the same at all floors. This principle was adopted for the design solution. And a pressure loss of 2.5 to $3 \mathrm{~Pa}$ was accepted as the design flow rate of an air outlet in the room under consideration.

For a collective flue or duct system the principle governing the adopted design solution is that the loss of pressure in the flue or duct is negligible and that the natural convection variation with each floor level is compensated for by the variation in the pressure loss of the air-outlet openings. In the interest of simplification, however, only two pressure-loss values were retained. These values for the design flow rate of the air outlet in the room under consideration, are:

--2.5 to $3 \mathrm{~Pa}$ on the last five floors;

--10 to $11 \mathrm{~Pa}$ on the other floors.

Cross sections corresponding to these pressure losses, in the case of large-mesh grilles, are: 
Cross section for a pressure

loss of:

2.5 to $3 \mathrm{~Pa} \cdot . \cdot . \cdot 80 \mathrm{~cm}^{2} 150 \mathrm{~cm}^{2} 220 \mathrm{~cm}^{2} 280 \mathrm{~cm}^{2}$ 10 to $11 \mathrm{~Pa}$..... $40 \mathrm{~cm}^{2} 80 \mathrm{~cm}^{2} 120 \mathrm{~cm}^{2} 150 \mathrm{~cm}^{2}$

Another possible solution is to provide "automatically controlled" (self-adjusting) air-outlet openings, whereby the flow rate would be independent of thermal circulation over a wide range of values for the latter.

2.12 Flue or Duct

Article 4 of the Decree distinquishes between:

--individual flue connected to only one room, and

-collective flue or ducts connected to several rooms on the same or different floors.

Described below are typical solutions for each of these two systems.

\subsection{Individual Flues or Ducts}

A. The pressure-loss value of $0.3 \mathrm{~Pa}$ per meter of length was retained as the design flow rate of the air outlet in the room being serviced, and as the maximum value of this flow rate in the case of an adjustable opening. 
Cross sections corresponding to this pressure loss in flues or ducts with very limited surface roughness, are:

\begin{tabular}{|c|c|c|c|c|}
\hline Flow Rate & $30 \mathrm{~m}^{3} / \mathrm{h}$ & $60 \mathrm{~m}^{3} / \mathrm{h}$ & $90 \mathrm{~m}^{3} / \mathrm{h}$ & $120 \mathrm{~m}^{3} / \mathrm{h}$ \\
\hline $\begin{array}{l}\text { Circular cross } \\
\text { section }\end{array}$ & $\begin{array}{l}80 \mathrm{~cm}^{2} \\
(\phi 10 \mathrm{~cm})\end{array}$ & $\begin{array}{c}120 \mathrm{~cm}^{2} \\
(\phi 12.5 \mathrm{~cm})\end{array}$ & $\begin{array}{c}160 \mathrm{~cm}^{2} \\
(\phi 14.5 \mathrm{~cm})\end{array}$ & $\begin{array}{c}200 \mathrm{~cm}^{2} \\
(\phi 16 \mathrm{~cm})\end{array}$ \\
\hline $\begin{array}{l}\text { Square cross } \\
\text { section }\end{array}$ & $\begin{array}{c}100 \mathrm{~cm}^{2} \\
(10 \times 10 \mathrm{~cm})\end{array}$ & $\begin{array}{c}155 \mathrm{~cm}^{2} \\
(12.5 \times 12.5 \mathrm{~cm})\end{array}$ & $\begin{array}{c}210 \mathrm{~cm}^{2} \\
(14.5 \times 14.5 \mathrm{~cm})\end{array}$ & $\begin{array}{c}255 \mathrm{~cm}^{2} \\
(16 \times 16 \mathrm{~cm})\end{array}$ \\
\hline $\begin{array}{l}\text { Rectangular } \\
\text { cross section } \\
\text { (as an example) }\end{array}$ & & & $\begin{array}{c}230 \mathrm{~cm}^{2} \\
(12.5 \times 18.5 \mathrm{~cm})\end{array}$ & $\begin{array}{c}290 \mathrm{~cm}^{2} \\
12.5 \times 23 \mathrm{~cm})\end{array}$ \\
\hline
\end{tabular}

Any cross section may be computed from a section that is already known, by applying the following rule:

--The area to perimeter ratio is constant.

The side of the square cross section is thus equal to the diameter of the circular cross section, and we pass from the square cross section to a rectangular cross section with a length to width ratio equal to e, by taking as length the side of the square multiplied by $(1+e) / 2$. However, in the case of a square or rectangular cross section for ease of cleaning, the smallest dimension should be at least equal to $12.5 \mathrm{~cm}$ for flues or ducts more than 5 meters in height and, in the other cases. more than 10 meters in height.

A flue or duct is considered to have little surface roughness, for example, when it is made of metal or asbestos cement and provided the joints or fittings do not create any bulging or projection. For the other ducts the cross sections will be larger.

B. Bends or slopes in the flues cause additional pressure losses and can impede cleaning. In the approved design solution it is assumed that there are no more than two bends, in other words not more than one 
nonvertical part with an angle generally no greater than $20^{\circ}$. However if the flue or duct has no surface roughness and is less than five meters in height, this angle can be greater than $20^{\circ}$ but no more than $45^{\circ}$.

\subsection{Collective Ducts}

Article 4 of the Decree provides for a collective duct system consisting of individual branch ducts as high as one floor with each branch duct connecting a room to a main (collector) duct. Recommended design solutions for these are given below.

\subsubsection{Individual Branch Ducts}

In the interest of simplification we adopted the same cross sections for individual ducts. Therefore, paragraph 2.121A should be consulted.

\subsubsection{Main (Collector) Duct}

The adopted design solution assumes, as stated above, that the pressure loss in the main duct is very limited. A maximum value of $0.15 \mathrm{~Pa}$ per meter of length was adopted for a flow rate equal to the sum of the design flow rates of the rooms being serviced, it being understood that when the opening is adjustable, the average of the extreme flow rates is used in this computation.

Figure 1 gives the cross sections corresponding to the above pressure loss in ducts having very little surface roughness. It is possible to pass from these cross sections to rectangular cross sections by applying the rule given in paragraph 2.12lA. However, for ease in cleaning, the smaller dimension should be at least $20 \mathrm{~cm}$. 
CSTB "Cahier" No. 720 (issue 83) provides some information on this problem. It also outlines the rationale behind the recommended design conditions for cap.

Article 4 of the Decree prescribes that the location of the vent on the roof and its cap must be such that the pressure depression created by the wind in the duct advantageously counteracts that created on the outside wall.

For the location, we propose to comply with the provisions of the regulations on flues or chimneys which the reader may therefore consult.

No recommended design solution is given for the cap, but we propose to retain the following design conditions:

A. The depression factor at zero flow rate or the ratio of the pressure depression created in the top part of the duct to the wind's dynamic pressure, is greater than 0.5 for all incidences of the wind forming an angle of less than $60^{\circ}$ with the horizontal plane;

B. The pressure loss in the absence of any wind and for a flow rate equal to the sum of the design flow rates of the room serviced, is less than $4 \mathrm{~Pa}$.

2.14 Special Case of a Flue or Chimney Connected to a Gas Appliance.

Article 5 of the Decree prescribes that a chimney exhausting combustion gases from gas appliances of Liquified-Petroleum-Gas appliances may be used as a duct for exhausting ventilating air. Actually some ventilating air is always exhausted through a gas appliance, but this air outlet may possibly be insufficient. We recommend the following 
various solutions in such a case:

--provide a second duct separate from the first;

--provide a second individual branch duct to the same

$$
\text { main (collector) duct; }
$$

--provide a second opening below the first opening within

the individual branch duct, or the individual duct

connected to the gas appliance.

It should be remembered that where flues or chimneys are concerned, those provisions of Article 24 of the 15 October 1962 Decree on flues or chimneys used for exhausting combustion products from connected gas appliances, must be complied with. This means that these flues must meet the specifications of the 14 November 1958 Decree on fixed heating facilities, and chimneys or flues, and the circular on flues or chimneys designed to service several fireboxes unless the flues in question are special flues designed to exhaust products of combustion solely from gas-fired appliances.

Instructions outlined in paragraph 2.12 are still applicable for computing cross sections.

\subsection{Air Inlets}

CSTB "Cahiers" No. 478 (issue 59), No. 542 (issue 65) and No. 720 (issue 83) outline the rationale behind the recommended design solutions in this paragraph. They also contain the calculations that produced pressure-loss and cross-section values adopted in these design solutions. 
Air inlets must make it possible to obtain the design flow rate of entering air under average thermal-circulation and wind conditions, while at the same time precluding any excessively high flow during a strong wind, thereby avoiding disagreeable cold drafts and inordinate heat loss by air change.

In the various design solutions described below, the data given varies with the different exposures to wind. In this connection, distinction is made between three types of sites: the "sheltered" site, the "exposed" site, and the "exceptionally exposed" site.

In the absence of any obvious evaluation data, the following guidance is applicable:

--First and second floors are in an exposed site only when in very windy locations and in the absence of nearby buildings;

--Levels between the second and seventh flloors are in a sheltered site only when the building is surrounded by equally high or higher buildings;

--All floor levels above the seventh floor are in an exposed site;

- The exceptionally exposed site is found along some coastlines, on the edges of some plateaus, on isolated elevations, and in very high buildings.

Three types of air inlets are considered in this document.

\subsection{Air Inlets on an Outside Wall}

These inlets are openings that directly interconnect the outside and inside. We do not propose to use this solution in exceptionally exposed sites. In other cases the flow rate is required to be: 
--at least equal to the design flow for any pressure differential between the outside and inside greater than $10 \mathrm{~Pa}$;

--and at the most, quadruple the design flow rate for any pressure differential below $60 \mathrm{~Pa}$ in a sheltered site, and below $240 \mathrm{~Pa}$ in an exposed site.

With fixed (nonadjustable) openings, this second solution is applicable only in a sheltered site. In this case, satisfactory results are obtained with cross sections having the following orders of magnitude:

$$
\begin{array}{lll}
\text { Flow Rate } & 30 \mathrm{~m}^{3 / h} & 60 \mathrm{~m}^{3} / \mathrm{h} \\
\text { Cross Section } & 35 \mathrm{~cm}^{2} & 70 \mathrm{~cm}^{2}
\end{array}
$$

In an exposed site "self-adjusting" openings should be used. The cross section of these openings varies with the wind pressure so that the flow rate is nearly constant throughout a wide range of values for this wind pressure.

\subsection{Air Inlet "by Horizontal Duct"}

A second solution approved for air inlets is the one called "by horizontal duct." Its principle involves capturing the air in a horizontal duct that opens out on two outside walls and is located on the same floor level as the dwelling (apartment) or in the lower part of the building. In the latter instance the air is fed into the apartment via a vertical duct. The approved characteristics for this design solution are as follows. 


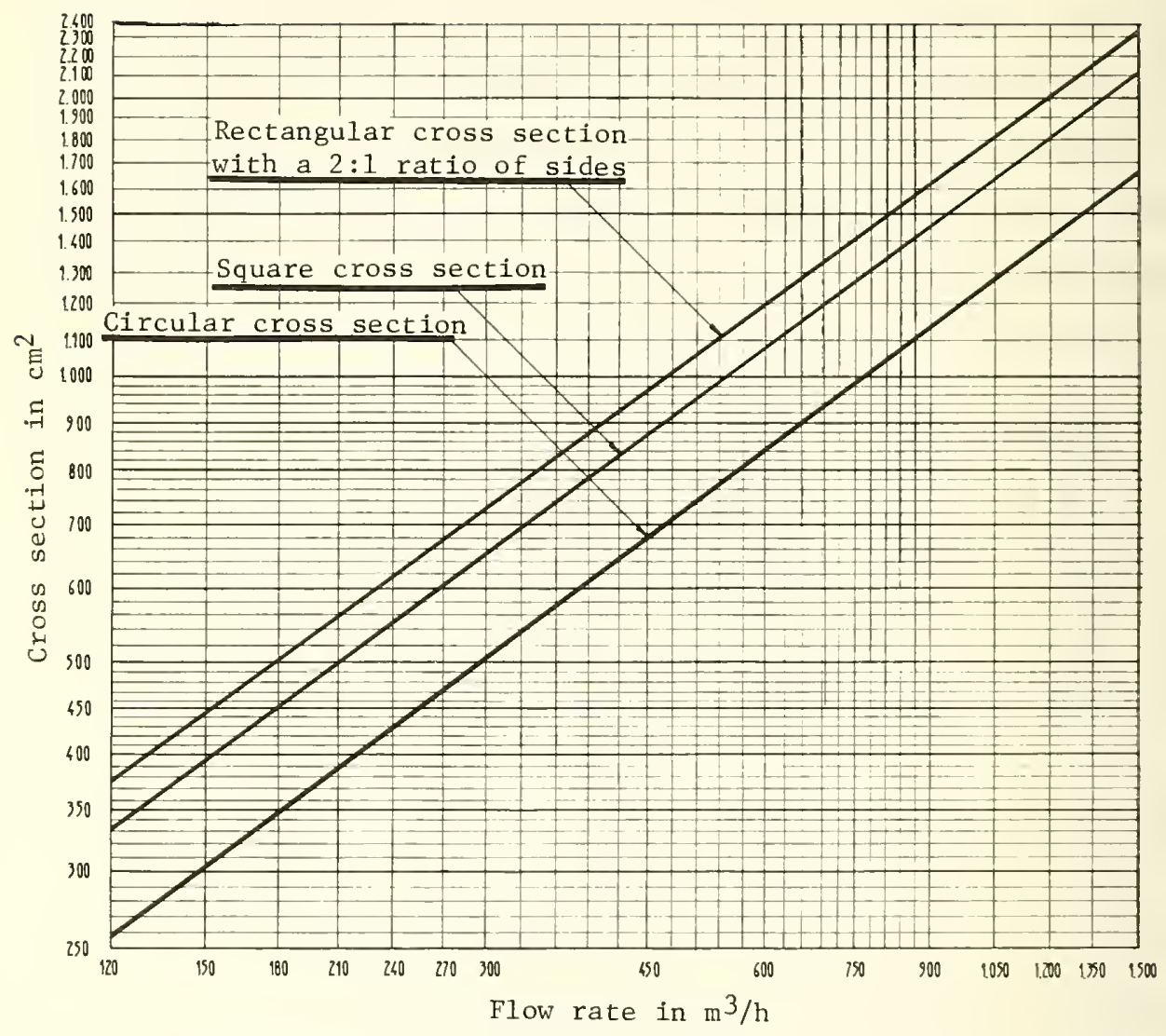

Figure 1. Cross section of smooth or slightly rough collective ducts for a pressure loss of $0.15 \mathrm{~Pa} / \mathrm{m}$ 
2.221 Horizontal Duct for Intake of Outside Air .

A. This duct opens out on two outside walls that are opposite each other or that together form an angle of at least $90^{\circ}$.

B. Its pressure loss per meter of length is not more than $0.15 \mathrm{~Pa}$ for a flow rate double the sum of the design flow rates of the air inlets served by the duct. The cross section can be calculated as described in paragraph 2.122.2, i.e. by using the curves in Figure 1 for ducts or flues having very little surface roughness and by adding certain augmented values for other ducts.

\subsection{Vertical Air-Intake Duct (where the horizontal duct is in the} lower part of the building).

This individual or collective duct is designed and its cross section is calculated according to the provisions prescribed for air-outlet ducts. When the duct is a collective one, it has individual branch ducts similar to the individual branch ducts of the air-outlet collective ducts, but in the reverse direction.

\subsection{Air-Inlet Opening in the Room}

Generally speaking, fixed openings are satisfactory. Their pressure loss is from four to five $\mathrm{Pa}$ for the design flow rate of the air inlet in the room under consideration. The cross sections corresponding to this pressure loss are of the following orders of magnitude.

$$
\begin{array}{lll}
\text { Flow Rate } & 30 \mathrm{~m}^{3} / \mathrm{h} & 60 \mathrm{~m}^{3} / \mathrm{h} \\
\text { Cross Section } & 60 \mathrm{~cm}^{2} & 120 \mathrm{~cm}^{2}
\end{array}
$$

In an exceptionally exposed site it could be advantageous to use self-adjusting openings to avoid excessive flow rates under strong-wind conditions. 
2.23 Air Inlets Used with a Mechanical Ventilation System and/or Associated with the Warm-Air Heating System.

Air inlets utilizing a mechanical system (device) and/or associated with the warm-air heating system can ensure proper intake of ventilating air if the following are provided:

--openings in all main rooms;

--sufficient intake of outside air at the beginning of air distribution so as to provide an air change at least equal to the sum of the design flow rates of the rooms served by this air distribution;

and if there is no:

--return into main rooms of air drawn from the service rooms (kitchens, bathrooms, toilets);

--return into an apartment of air drawn from another apartment.

\subsection{Pressure Losses inside a Dwelling}

\subsection{Air Passages Leading from the Main Rooms into the Service Rooms}

Justification for the pressure-loss and cross section values given in this paragraph may be found in CSTB "Cahier" No. 542 (issue 65).

The characteristics of the air inlets and air outlets adopted for those design solutions described earlier in this document, require that the pressure loss in the openings that draw air from the main rooms into the service rooms--openings specifically designed for this purpose or natural openings around the perimeter of the doors--should not be more than one $\mathrm{Pa}$ for the corresponding design flow rate. It should be 
understood that for those service rooms having a controllable air-outlet flow rate, the minimum value of this flow rate is used herein.

The cross sections corresponding to this pressure loss are:

$$
\begin{array}{lll}
\text { Flow Rate } & 30 \mathrm{~m}^{3} / \mathrm{h} & 60 \mathrm{~m}^{3} / \mathrm{h} \\
\text { Cross Section } & 100 \mathrm{~cm}^{2} & 200 \mathrm{~cm}^{2}
\end{array}
$$

To avoid excessive passage of light it is advisable to have, for example, some sort of baffle or deflector arrangement between the door and the door frame.

\subsection{Airtight Door inside a Dwelling}

The value used in this paragraph is taken from the Joint Instructions of the European Union for Approved Building Techniques, published in CSTB "Cahier" No. 855 (issue 98).

If one wishes to have separate ventilation for each of two parts of the dwelling (apartment), the inside door separating these two parts must have a low degree of permeability: a value equal to $12 \mathrm{~m}^{3} / \mathrm{hm}^{2}$ for a pressure difference of $100 \mathrm{~Pa}$ seems to be a reasonable maximum.

As an example, the apartment may be separated into two separate parts for this purpose:

--living room and kitchen as one part, and --bedrooms, bathroom, and toilet as the other. 
CHAPTER 3: DESIGN SOLUTIONS FOR PERMANENT AND GENERAL VENTILATION OF A DWELLING WITH A MECHANICAL AIR-EXHAUST SYSTEM (Articles 6 and 7 of the Decree)

\subsection{Air Outlets}

Discussions in support of the statements in this chapter may be found in CSTB "Cahier" No. 590 (issue 70) and also in the foreign bibliography listed therein.

\subsection{Overall Air-Exhaust Circuit}

The concept of the exhaust circuit is derived from calculation and not from a design solution. One element of the calculation is the limitation on flow rate variations caused by the presence of manually adjustable openings in some rooms (kitchens and drying rooms), and also by those variations in thermal circulation that occur with changes in outside temperature.

We recommend that these variations be limited to no more than:

--20 percent when due to a change in the flow rate by manual adjustment of openings (in kitchens or drying rooms), and

--30 percent when due to variations in thermal circulation between winter and summer.

To accomplish this, the pressure loss of the air-outlet openings should generally be greater than:

$--40 \mathrm{~Pa}$, and

--50 percent, and even better 60 percent of the pressure losses

in the overall exhaust circuit involving the opening under consideration, with the adjustable openings being in the halfopen position. 
Moreover, once a certain floor level is reached in a building, other special measures may have to be taken. These may, as an example, include:

--the capability to constrict or throttle flow in the lower

floors during the heating period,

--automatically controlled (self-adjusting) air-outlet openings.

\section{$\underline{3.12 \text { Ducts }}$}

Ducts may be vertical, inclined, or horizontal. Circuit simplicity is always desirable, especially so as to facilitate cleaning. Paragraph 5.1 further discusses such cleaning.

As regards the type and quality of the ducts great importance must be attached to their airtightness, given the pronounced pressure depression that prevails within them. We recommend adopting as maximum admissible air infiltration through ducts and joints, the value of 10 per cent of the flow rate through the air-outlet openings.

\subsection{Exhaust Fan (extractor)}

The choice of the exhaust fan is based on calculation and not on a design solution.

Certain precautions must be taken in selecting its location. The contaminated air must be discharged outside of areas through which people pass, for example, that part of a roof terrace open to the public. If need be, shields or screens should be provided to avoid all wind disturbances.

\subsection{Air Inlets and Pressure Losses within a Dwelling.}

The statements in paragraphs 2.2 and 2.3 of Chapter 2 are still valid here. However, in view of the powerful draw (draft) available with 
the mechanical exhaust system, values greater than those indicated in Chapter 2 can be allowed for pressure loss in air inlets and in the air passages leading from main rooms into service rooms.

Specifically, the pressure loss in air passages leading from main rooms into service rooms may reach $3 \mathrm{~Pa}$ for the corresponding design flow rate. The following cross sections correspond to this pressure loss:

$$
\begin{array}{lll}
\text { Flow Rate } & 30 \mathrm{~m}^{3} / \mathrm{h} & 60 \mathrm{~m}^{3} / \mathrm{h} \\
\text { Cross Section } & 60 \mathrm{~cm}^{2} & 120 \mathrm{~cm}^{2}
\end{array}
$$

\subsection{Presence of Flues or Chimneys}

Article 7 of the Decree defines the general requirements whenever there are flues or chimneys in dwellings equipped with a mechanical air exhaust system.

In certain cases--listed in paragraph 3.31 --these requirements are met without it being necessary to make any special arrangements for the chimneys. On the other hand, in some other cases it is necessary to take special measures. A few design solutions to this problem are given in paragraph 3.32 .

\subsection{Case in Which Only the Customary Measures Need Be Taken.}

3.311 This is the case, first of all, when the air intake is supplied mechanically. In this instance, the overpressure caused by the blast (insufflation) of the entering air counterbalances the reduced pressure caused by the exhaust of the outgoing air. 
This assumes, however, that:

A. The air-intake flow rate in a dwelling is close to the air-outlet flow rates;

B. The intake of "pulsed" air operates at all times when the mechanical exhaust system is in operation, and, in the event of a breakdown in the "pulsed"-air system, the mechanical exhaust system automatically shuts down.

3.312 Then there is the case of a chimney connected to a heating unit located in a room or space that is not ventilated by the dwellings' ventilation system, e.g. cellar, storeroom or wine cellar. . . . In such cases the door between this room or space and the dwelling proper must be very airtight.

3.313 It is also the case in individual facilities, where, if difficulties arise at the moment of ignition (lighting), the mechanical exhaust system can be momentarily shut down without difficulty.

\subsection{Design Solutions for Those Cases Where It Is Necessary To Take}

Measures That Differ from Those Customarily Adopted.

In all cases, other than those described in paragraph 3.31 , measures must be taken to insure that:

--there is no danger whatever of backflow (backdraft) particularly at the moment of ignition, despite the constant suction of the ventilation ducts or conduits, both when the dwelling is being heated and when it is not. 
--when the fumes or smoke are drawn off mechanically, there is no danger whatever in the event of a breakdown in this mechanical exhaust system.

The following design solutions satisfy these conditions.

3.321 Use of Apparatus with "Excluded" Combustion Circuit

This is the case, for example, of gas appliances connected to "S.E.-Ducts."

3.322 Individual Outside-Air Inlet into the Firebox, and Flue Operating by Thermal Circulation (chimney effect) under Normal Conditions. This solution is applicable, for example, to fireplaces. In this case:

A. The flue or chimney is constructed as for normal conditions (it should be recalled that fireplaces require a separate flue);

B. The air inlet and the smoke or fume outlet must be equipped with adjustable dampers;

C. The fireplace has a movable register or shutter by which the firebox (hearth) can be excluded from the dwelling's atmosphere when lighting the fire.

3.323 Flue Operating with Assistance of a Mechanical Exhaust System Independent of the Ventilation.

This solution may, for example, consist in installing an exhaust fan at the top of the chimney. In this case the following measures should be taken: 
A. If no heating unit has yet been connected to the chimney, a sealed plate specifies that such connection must be made by qualified specialists;

B. Measures are taken so that in the event of a breakdown in the mechanical smoke and fume system:

--either the connected heating unit shuts down, something that is not possible with all fuels;

--or the connected heating unit continues to function by thermal circulation, this implies that:

1. The reduced pressure created in the dwelling by mechanical ventilation disappears, and thus that this ventilation automatically stops in case of a breakdown in the mechanical smoke exhaust system;

2. There is no excessive pressure loss at the top of the chimney. This condition should normally be obtained with a fan that works by induction. With a fan working by extraction:

--a first solution is to provide a device that in case of breakdown, cuts off the mechanical exhaust duct, and opens a natural exhaust duct.

--a second solution is to use an exhaust fan that in the event of a breakdown has a small pressure loss.

\subsection{Use of Exhaust Fan To Extract Smoke and Fumes}

This solution is applicable, for example, to fireplaces. In this case : 
A. The flues--individual separate flues because fireplaces are involved--can be grouped at their tops into a collective flue opening into the extraction chamber;

B. An adjustable damper is installed at the base (start) of each flue ;

C. Measures are taken so that if there is a breakdown in mechanical extraction, fireplaces continue to function by thermal circulation. The statements on this subject in paragraph 3.323-B-2 are still applicable here.

3.325 A Smoke and Fume Extraction System Associated with a Mechanical Ventilating Air Exhaust System.

This solution is applicable, for example, to connected gas appliances. In this case:

A. Connecting the appliance to the duct entails an adequate pressure loss, calculated for the appliance's operating flow rate.

B. If the air-outlet design flow rate needed to ventilate the room in which the appliance is located, is greater than the appliance's operating flow rate--which may be the case in a kitchen--provision is made for another air-outlet opening calculated to supply the additional flow rate.

C. The duct meets specifications for flues used to exhaust the products of combustion from connected gas appliances, given in Article 24 of the 15 October 1962 Decree. This means that the flue conforms to the provisions of the 14 November 1958 Decree on fixed heating facilities, and flues or chimneys, and to the circular on flues designed to serve several 
fireboxes, unless it is a flue especially designed to draw off the products of combustion from only gas-fired appliances.

D. An automatic device is provided to halt combustion in the event of a breakdown.

CHAPTER 4: DESIGN SOLUTIONS FOR PARTIALLY INTERMITTENT VENTILATION AND FOR VENTILATION BY SEPARATE ROOMS (Article 8 of the Decree)

Article 8 of the Decree provides for the possible use in certain cases of natural ventilation arrangements that differ from those for which design solutions were offered in Chapter 2. The following design solutions are recommended for these new arrangements.

4.I Kitchen Ventilation by Means of an Air Inlet and a Vertical-Duct Air Outlet, Both Located in the Kitchen.

Design solutions adopted for the air outlet are those defined in paragraph 2.1, Chapter 2. Design flow rates for the air outlet are as defined in paragraph 1.12 , Chapter 1.

Design solutions adopted for the air inlet are those defined in paragraph 2.2, Chapter 2, with the design flow rate for the air inlet being $60 \mathrm{~m}^{3} / \mathrm{h}$.

4.2 Ventilation of Service Rooms Other Than the Kitchen, by a Hinged Opening into a Vertical Duct 
Justification for what is said below may be found in CSTB "Cahier" No. 542 (issue 65).

\subsection{Hinged Opening}

A. The cross section of the opening is at least $0.1 \mathrm{~m}^{2}$.

B. If the opening is in a vertical duct serving several apartments, measures must be taken to prevent seeing directly from one apartment into the other, and to preclude the possibility of a man passing through the opening, and also to deter, to a practical extent, the throwing of objects into it. One solution would be to place the opening as high as possible, fit it out with nontransparent materials, and position it on a horizontal axis. This axis could be positioned in the middle of the opening so as to take maximum advantage of the vertical draft present in the duct. Stops could be provided which would allow the opening to be kept partially open in an intermediate position, thus making it possible to regulate the amount of ventilation consistent with requirements.

\subsection{Vertical Duct}

Since in a vertical duct, the lower the duct the easier it is to obtain satisfactory air change, we recommend a different principle depending on whether the duct is in a single-family house or in a multiple-dwelling building. Moreover, in each of these two categories we recommend different cross sections that vary with the number of floors serviced.

4.221 Case of Single-Family Houses Constructed as Separate, Duplex, or Row (town) houses. 
The recommended design solution is as follows:

A. The duct opens to the outside in its upper part.

B. Its cross section is at least $0.1 \mathrm{~m}^{2}$ if it serves only one floor, and at least $0.2 \mathrm{~m}^{2}$ if it serves more than one floor.

C. Specifications for the vent outlet on the roof are as given in paragraph 2.13 .

\subsection{Case of Multiple-Dwelling Buildings}

The recommended design solution is as follows:

A. The duct opens onto the outside in both its upper and lower parts.

B. Its cross section is at least $1 \mathrm{~m}^{2}$ for buildings of less than six floors and at least $1.5 \mathrm{~m}^{2}$ for others.

C. In the lower part, the opening to the outside is provided by a horizontal duct of the same cross section as the vertical duct. This horizontal duct opens onto two outside walls that are opposite to each other or that together form an angle of at least $90^{\circ}$. As an exception, this horizontal duct may be eliminated when the vertical duct emerges above an open passageway or a (covered) school playground. In such a case the bottom part of the duct is reinforced so as to be able to hold any heavy objects and thus protect persons underneath.

D. In the upper part, the vent emerging on the roof meets those specifications listed in paragraph 2.13. 
CHAPTER 5: TYPICAL DESIGN SOLUTIONS RELEVANT TO CLEANING FACILITIES, PROTECTION AGAINST COLD DRAFTS, AND NOISE CONTROL

$$
\text { (Article } 9 \text { of the Decree) }
$$

\subsection{Cleaning Facilites}

The problem arises mainly with respect to ducts. For these we recommend adoption of the following principle:

Ducts may be cleaned:

--from common-use rooms or spaces, in the case of collective duct systems;

--from common-use rooms or from apartments, in the case of individual ducts, and of individual branch ducts in collective systems.

In a natural ventilation system, the minimum cross-section rules recommended in paragraphs 2.121 and 2.122 .2 of Chapter 2 should permit compliance with the above principle.

In a mechanical ventilation system, such compliance may present problems when there are individual branch ducts. We recommend that in this case:

--the smallest cross-sectional dimension of the individual branch ducts must not be less than $10 \mathrm{~cm}$ for the kitchens, nor less than $9 \mathrm{~cm}$ for the other service rooms;

--the branch ducts must be rectilinear save for an exceptional, single bend with an angle of less than $30^{\circ}$, unless there are cleaning traps in the elbows. 
CSTB "Cahiers" No. 478 (issue 59) and No. 720 (issue 83) contain the rationale supporting the general principle and special design solutions presented in the paragraph that follows.

On this point, we shall first propose a general principle, and then some special design solutions.

\subsection{General Principle}

The general principle propounded is that the "discomfort index" determined with an outside temperature of $0^{\circ} \mathrm{C}$, an inside temperature of $20^{\circ} \mathrm{C}$, and a flow rate equal to the "practical flow limit in a strong wind," does not exceed $2^{\circ} \mathrm{C}$ throughout that zone located at a height of less than two meters and a distance of more than 20 centimeters from the vertical walls, with this result being obtained under normal heating conditions. The discomfort index and the practical flow limit in a strong wind are defined in the two following paragraphs.

\subsection{Discomfort Index}

The discomfort index of a cold draft of air at a given point in a room is equal to the sum of:

--the difference between the average air temperature of the room at the same level, and the temperature of the air stream at that given point;

--and the equivalent drop in temperature expressing the effect of air-stream velocity at that point; as given in Figure 2. 
Figure 2: Equivalent Drop in Temperature Reflecting the Effect of Air-Stream Velocity

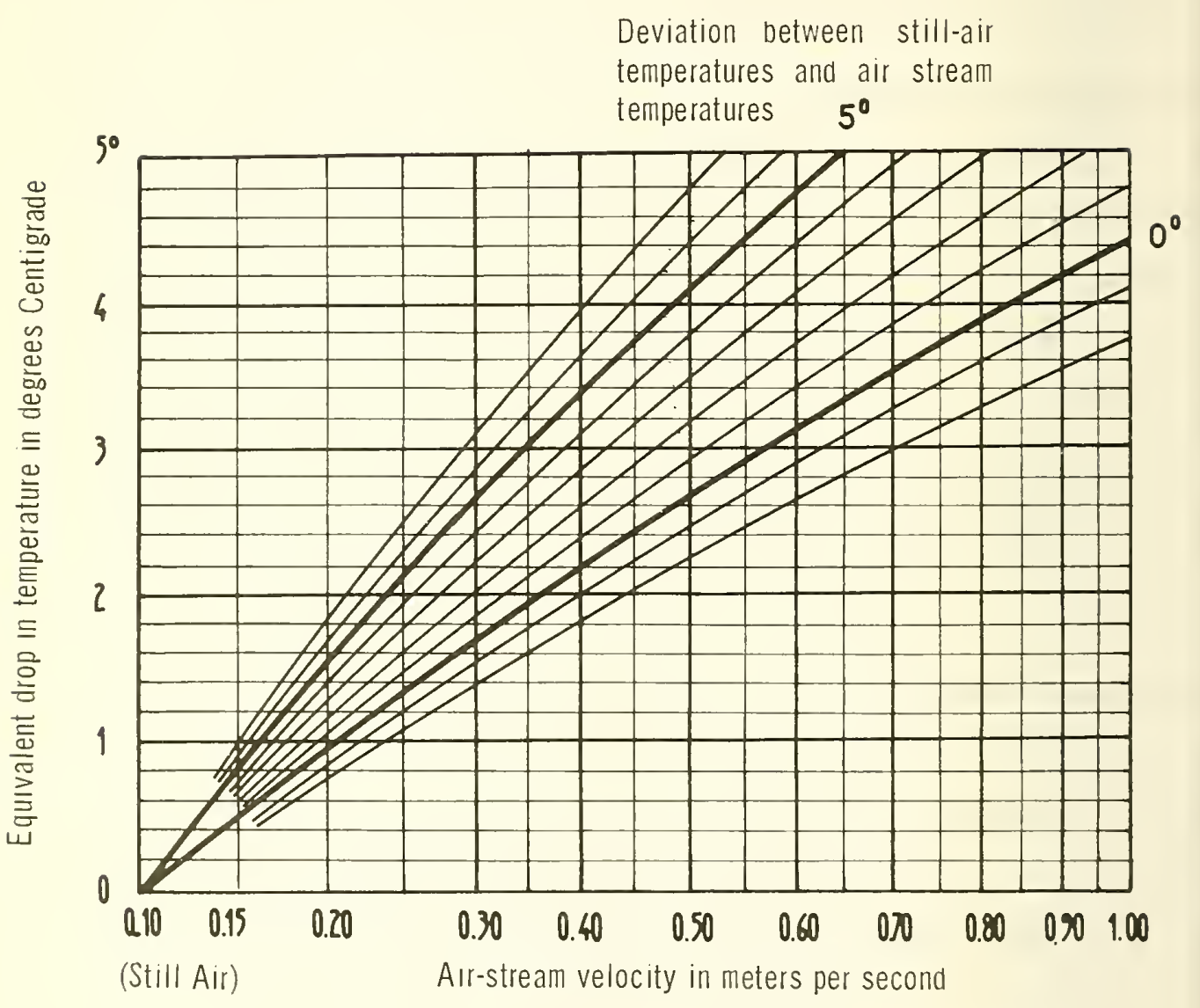


5.212 Practical Flow Rate Limit in Strong Wind

A. Air inlets on outside walls.

For fixed inlet openings (which in the adopted design solution are admissible solely in a sheltered site), the practical flow limit is equal to four times the design flow rate.

For self-adjusting openings (automatically controlled), the practical flow limit is equal to the maximum flow rate attained with a pressure differential between outside and inside amounting to a maximum of:

-- $60 \mathrm{~Pa}$ in a sheltered site, --240 $\mathrm{Pa}$ in an exposed site.

B. Air inlets by horizontal duct.

For fixed inlet openings, the practical limit is equal to or double the design flow rate in a sheltered site, and quadruple the design flow in an exposed site.

For self-adjusting openings, the practical flow limit is equal to the maximum flow rate obtained with a pressure loss reaching up to:

-- $60 \mathrm{~Pa}$ in a sheltered or exposed site,

--240 $\mathrm{Pa}$ in an exceptionally exposed site.

C. Air inlets in a mechanical ventilation system and/or inlets associated with a warm-air heating system.

When air inlets are connected to the warm-air heating system no problem should normally be encountered with disagreeable cold-air drafts.

For mechanical air inlets not associated with a warm-air heating system, the practical flow limit with a strong wind should normallly be equal to the design flow rate. 


\subsection{Special Design Solutions}

Generally speaking, adherence to the principle propounded above implies combining heating and ventilation. Air may be heated before entering the room or enter the room near a heat-emitting source. In the latter case, special arrangements are required depending on the type of heat emission. The following design solutions, among others, are possible:

A. Air inlet combined with radiator heating. The air-inlet opening is elongated and located behind or above a radiator. A deflector is mounted on the radiator so as to direct the incoming air upward and thus mix cold air with the ascending current of warm air produced by the radiator. Should any shelves or covers be placed on the radiator, they must be such as not to impede this process.

B. Air inlet combined with floor or ceiling panel heating. The air inlet is installed under the floor in such a way that the cold air is diffused within the layer of warm air at or below the floor before reaching the occupied zone. This result can be obtained by either a series or strip of openings distributed over a sufficient length, or be a diffuser of adequate design and shape.

Since these measures may possibly have some effect upon heating facilities (power of value of the heat emission, danger of freezing or frost...) it is advisable to take these measures into account when designing the heating system.

\subsection{Noise Control}

Those recommendations made in Title 6 of this Technical Report are reiterated in the following paragraphs along with some additional comment. 
5.31 Control of Noise Transmission between Apartments

Information on this problem may be found in CSTB "Cahier" No. 590 (issue 79).

The general recommendation on sound insulation given in Title 6 of this Technical Report (paragraph 2.1) is that standardized sound attenuation between apartments must be at least equal to $36 / 48 / 54$ decibels. These values apply to low-pitch, medium-pitch, and high-pitch frequency bands respectively.

To understand what this recommendation entails for ventilation, we may reason as follows:

If the type of construction by its very nature permits achieving a suitable degree of insulation, then the ventilation ducts should not be the cause of any appreciable attenuation in the quality of the insulation. If we grant that this attenuation must not exceed one decibel, and if we consider a building with solid $15 \mathrm{~cm}$ thick concrete walls and floors, we arrive at the practical (working) rule that standard attenuation corresponding solely to transmission via the ducts must be at least $43 / 55 / 55$ db between different dwellings.

Actually, when ventilation ducts are the cause of insufficient attenuation, they are so for one of the following reasons:

--the sound is transmitted from the opening of an air outlet or air inlet to another such outlet or inlet by propagation through the air in the duct;

--housing one or more ducts inside a wall separating two apartments, reduces the mass of the wall and, consequently, its insulation. 
1. Transmission by propagation through the air in the duct.

A. In the case of natural ventilation, compliance with the practical rule given above requires that, with collective ducts, certain special precautionary measures be taken to absorb sound. For example, sound-absorbing material can be applied inside the ducts; and the larger the cross-section area of the ducts, the more such action is required.

B. In the case of mechanical ventilation, the small cross sections of the openings are generally sufficient to provide the desired insulation despite the absence of individual "feeders." When this is not the case, then provision should be made, as an example, for the following:

--individual "feeders";

--sound-absorbing material on the inside surfaces of the ducts;

--inside surfaces of the ducts; or "mufflers."

It is also important to make sure that the openings do not generate any whistling or disagreeable vibration when subjected to the velocity of the air passing through them.

2. Risk of reducing the insulation quality of a wall.

As a general rule, ducts should be built against, and not inside, those walls that provide sound insulation between apartments. If, however, the ducts are specially designed for in-wall installations, they could be so incorporated, but on condition that they provide a degree of sound insulation between rooms that is consistent with the general rule mentioned above. 
Ventilation System.

In this document we shall simply quote the general instructions given in paragraph 4, Title 6 of this Technical Report:

"Noises whose sound level does not exceed $30 \mathrm{db}(\mathrm{A})$ in a bedroom and $35 \mathrm{db}(\mathrm{A})$ in a living room, are generally acceptable to the occupants. These levels correspond to $35 \mathrm{db}(\mathrm{A})$ and $40 \mathrm{db}(\mathrm{A})$ respectively, when the rooms are bare (not furnished)."

Table 1. Conversion Factors

\begin{tabular}{|c|c|c|c|c|c|c|}
\hline $1 \mathrm{ft}$ & $=0.305$ & m & & 30.48 & $\mathrm{~cm}$ & \\
\hline $1 \mathrm{~m}$ & $=39.4$ & in & $=$ & 3.28 & $f t$ & $=1.1$ \\
\hline $1 \mathrm{~cm}$ & $=0.39$ & in & $=$ & 0.033 & $f t$ & $=0.011 \mathrm{yd}$ \\
\hline $1 \mathrm{~m}^{2}$ & $=10.8$ & $f t^{2}$ & $=$ & 1.20 & $y d^{2}$ & \\
\hline $1 \mathrm{ft}^{2}$ & $=0.09$ & $m^{2}$ & $=$ & 0.11 & $y d^{2}$ & \\
\hline $1 \mathrm{yd}^{2}$ & $=0.84$ & $m^{2}$ & $=$ & 9.0 & $f t^{2}$ & \\
\hline $1 \mathrm{~m}^{3}$ & $=35.3$ & $f t^{3}$ & $=$ & 1.31 & $\mathrm{yd}^{3}$ & \\
\hline$y d^{3}$ & $=27.0$ & $f t^{3}$ & $=$ & 0.76 & $m^{3}$ & \\
\hline
\end{tabular}

$\mathrm{Pa}=\mathrm{Pascal}$, Newton $/ \mathrm{m}^{2}$

$1 \mathrm{~Pa}=0.00401474$ in water gauge pressure

${ }^{\circ} \mathrm{C}=(\mathrm{F}-32) / 1.8$ 


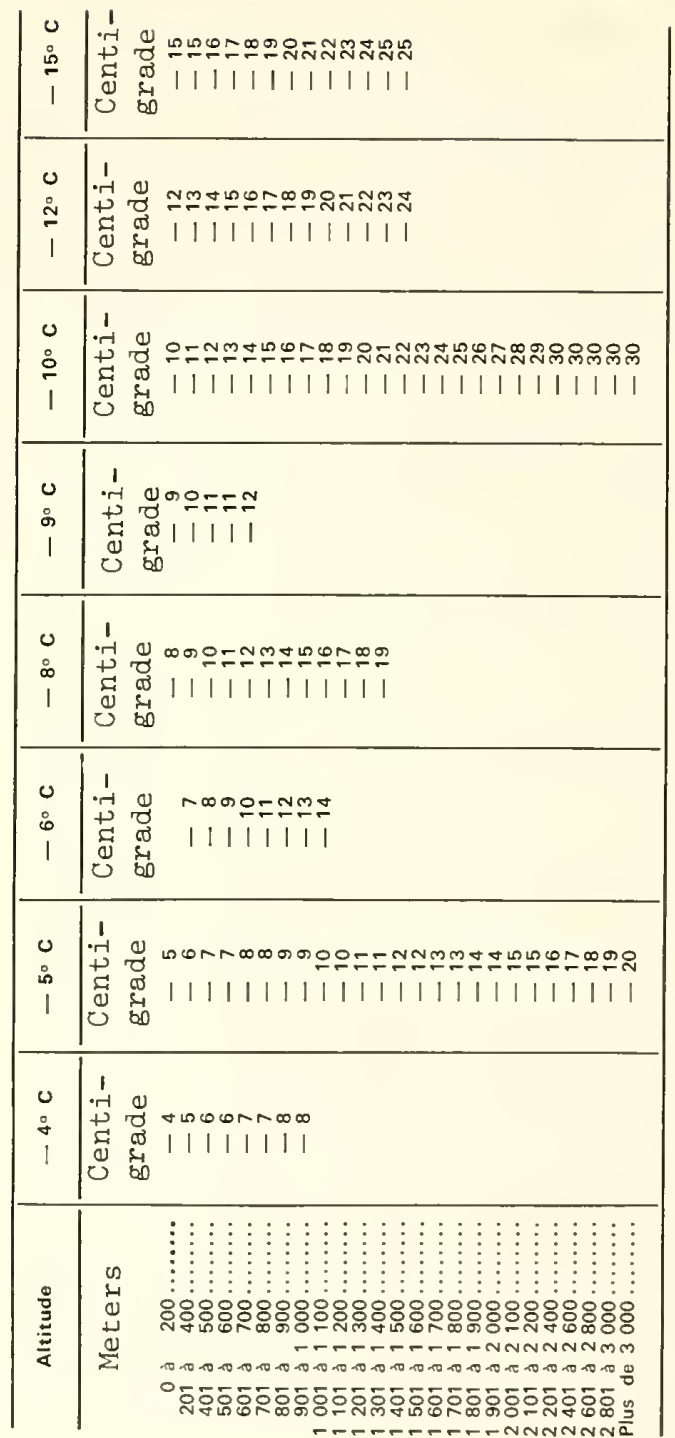

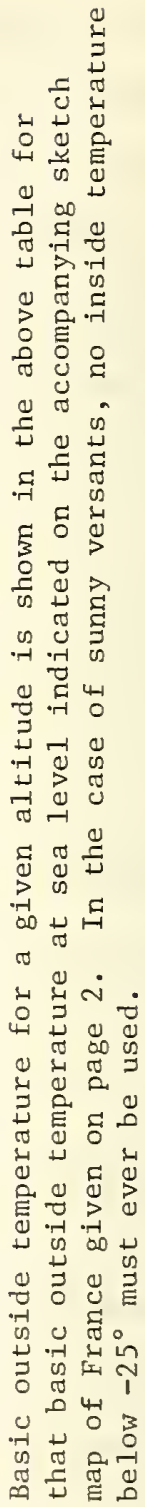


APPENDIX

DECREE OF 30 APRIL 1969

VENTILATION OF DWELLINGS

The Minister of State for Social Affairs, the Minister of Equipment and Housing, and the Secretary of State for Equipment and Housing;

Considering Executive Order No. 55-1394, 22 October 1955 prescribing general rules governing the construction of residential buildings referred to in Article 92 of the Housing and Urbanism Code, specifically Article 8 , 11 , and 12 of that Executive Order;

Considering the Decree of 15 October 1962, prescribing technical and safety rules applicable to gas or liquefied petroleum appliances installed inside dwellings or their outbuildings;

Decree:

Article One. The provisions of this decree are designed to permit adequate air changes in dwellings so that the levels of contaminants present, particularly with regard to exhaust gases and moist air, are compatible with the health and comfort of the occupants, and with the absence of possible condensation.

Article Two. The ventilation system in dwellings shall be so designed as to provide continuous ventilation at least during periods when the temperature requires that windows remain closed. Moreover, the design will be such that air enters the dwelling via the main rooms (bedrooms, living rooms) and leaves it mainly via those rooms in which most of the contaminants and water vapor are produced (kitchens, bathrooms, 
laundry rooms, drying rooms, toilets), with this air being exhausted naturally by thermal circulation or by mechanical means.

For implementation of the above provisions, the dwelling may be treated as one single space or it may be divided into several parts separated by doors that are sufficiently airtight.

Inside the dwelling, or if it is divided, inside its separate parts, outlets with an adequate cross-sectional area shall allow the air to circulate freely and continuously from those rooms where the outside air enters the dwelling into the rooms where the air leaves it.

As an exception, in those special cases described in Article Eight, separate ventilation may be provided in each room, and in some rooms it may be intermittent.

Article Three. In designing a ventilation system the distrubing effects of the wind must be taken into account. The building must be constructed so as to satisfy the system calculation assumptions, especially by ensuring that the following are more or less airtight to a great extent: outside metal and woodwork and sashes, landing doors, and inside doors.

Article Four. The flues or ducts designed to exhaust the air by thermal circulation may be individual or collective. The former lead directly outside from only one room. The collective system serves several rooms on the same or different floors by means of individual branch ducts leading from each room into the main exhaust duct. Branch ducts used to exhaust air from kitchens cannot be connected to branch ducts leading from other service rooms, except other kitchens. 
The cross section of collective ducts or flues is such that the pressure loss in them is negligible and the individual branch ducts are one-story high.

The location of the outlet on the room and its cap are such that the reduced pressure created by the wind in the duct advantageously counterbalances the reduced pressures created on outside walls.

Article Five. A flue or chimney used to remove combustion gases from gas or liquefied petroleum appliances may also serve as a ventilation air-outlet duct, providing the exhaust from furnaces utilizing other fuels cannot be connected to that duct.

Article Six. When the ventilation system involves mechanical extraction of foul air, all rooms in a same dwelling must be connected to a same exhaust fan or to a few fans that can only function simultaneously. For those facilities servicing more than two dwellings, two independent motors are employed or else the exhaust-fan motor is supplemented by a backup motor that starts up automatically, or very easily, whenever the main motor breaks down.

Article Seven. In the case of ventilation by mechanical extraction, if there are flues or chimneys handling smoke or exhaust gases, they must be designed so that the reduced pressure created in the dwellings for ventilation cannot entail a downdraft, particularly when fireboxes are being ignited.

If this result is obtained with mechanical extraction of smoke, fumes, or exhaust gases, the system must provide that in the event of a breakdown, all smoke or fumes are removed by thermal circulation or there is automatic shutdown of combustion. 
Article Eight. In separate, duplex, or row single-family dwellings, and in those dwellings located in the following departments and below an altitude of 200 meters: Alpes-Maritimes, Aude, Basses-Pyrennes, Bouchesdu-Rhone, Charente-Maritime, Corsica, Gard, Gironde, Herault, Landes, Loire-Atlantique, Pyrennees-Orientales, Var, Vaucluse, and Vendee, unless there is a mechanical exhaust system in the dwelling, each room may be ventilated separately and the mandatory requirement for permanent ventilation remains applicable only for the kitchen.

In such a situation, permanent ventilation of the kitchen shall be provided by exhausting the air through a vertical flue or duct; the corresponding air inlet may be located in the kitchen.

If ventilation of the other rooms is nonmechanical and separate, it will be provided by a hinged opening to the outside or into a vertical duct.

Article Nine. Air-inlet and air-outlet equipment must be designed to facilitate cleaning.

All mechanical systems must be inspected periodically. Air-inlets must be so designed as not to be a cause of thermal discomfort for the occupants. This implies that heating and ventilation design studies be conducted simultaneously. To limit disturbing wind effects, these air inlets may be adjustable or controllable, but it should not be possible to close them completely.

New air may be heated, cooled, or conditioned before being introduced into the dwelling.

Article Ten. The decree of 14 November 1958 on ventilation of dwellings is rescinded. 
Compliance with the provisions of Articles One to Nine above shall not be mandatory in the case of:

--those applications for building permits filed prior to 1 January 1970; and also

--those applications for building permits based on plans having been the subject of a building permit issued prior to 1 January 1970, and likely to be the subject of private contracts in the meaning of the public contracts code, or constituting the end of a contract extending over several years and signed prior to 1 January 1970, for which the rules in force prior to the issuance of this decree may still be applied, on condition that in that case the provisions of the decree of 14 November 1958 on fixed heating facilities and flues, as amended by the decrees of 13 May 1960 and 5 June 1961, shall likewise be applied.

Article Eleven. The Director of Land and Urban Development, the Director of Construction, and the Director-General of Public Health, are entrusted, each within his area of responsibility, with the execution of this decree that shall be published in the "Journal Officiel" of the French Republic.

Done at Paris, on the thirtieth day of April 1969.

Minister of Equipment and Housing, Albin Chalandon.

Minister of State for Social Affairs, Maurice Schumann.

Secretary of State for Equipment and Housing

Philippe Dechartre 
FORM NBS-114A (1-71)

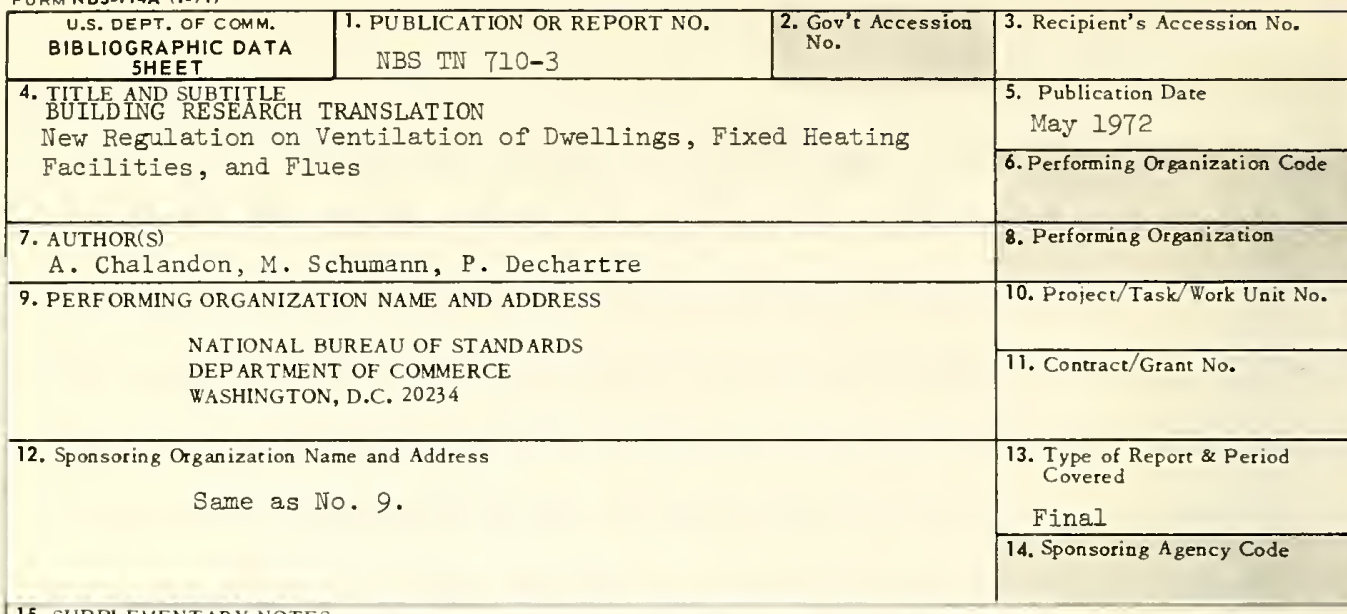

15. SUPPLEMENTARY NOTES

C.S.T.B. No. 101, July/August 1969, Cahier 879

16. ABSTRACT (A 200 -word or less factual summary of most significant information. If document includes a significant bibliography or literature survey, mention it here.)

Following studies on the ventilation of dwellings, the results of which have been published in CSTB "Cahiers," the CSTB has proposed certain changes in the regulations governing the ventilation of dwellings. At the same time, in the light of recent statistics on secondary emergency and relief heating, changes in the regulations governing fixed heating installations and flues were proposed. These proposals led to a new revised text of the French regulations, which we publish below, together with a new chapter on "ventilation" from the CSTB Technical Report.

17. KEY wORDS (Alphabetical order, separated by semicolons) Air infiltration and extraction, airtightness; discomfort index; duct system, collective and individual branch; flow rates; noise; pressure-loss-depression; thermal convection; ventilation.

\begin{tabular}{|c|c|c|}
\hline $\begin{array}{l}\text { 18. AVAILABILITY STATEMENT } \\
\mathrm{X} \text { UNLIMIT ED. }\end{array}$ & $\begin{array}{l}\text { 19. SECURITY CLASS } \\
\text { (THIS REPORT) } \\
\text { UNCL ASSIFIED }\end{array}$ & $\begin{array}{c}\text { 21. NO. OF PAGES } \\
46\end{array}$ \\
\hline
\end{tabular}


PERIODICALS

JOURNAL OF RESEARCH reports National Bureau of Standards research and development in physics, mathematics, and chemistry. Comprehensive scientific papers give complete details of the work, including laboratory data, experimental procedures, and theoretical and mathematical analyses. Illustratcd with photographs, drawings, and charts. Includes listings of other NBS papers as issued.

Published in two sections, available separately:

\section{- Physies and Chemistry}

Papers of interest primarily to scientists working in these fields. This section covers a broad range of physical and chemical research, with major emphasis on standards of physical measurement, fundamental constants, and properties of matter. Issued six times a year. Annual subscription: Domestic, $\$ 9.50 ; \$ 2.25$ additional for foreign mailing.

\section{- Mathematical Sciences}

Studies and compilations designed mainly for the mathematician and theoretical physicist. Topics in mathematical statistics, theory of experiment design, numerical analysis, theoretical physics and chemistry, logical design and programming of computers and computer systems. Short numerical tables. Issued quarterly. Annual subscription: Domestic, $\$ 5.00$; $\$ 1.25$ additional for foreign mailing.

\section{TECHNICAL NEWS BULLETIN}

The best single source of information concerning the Bureau's measurement, research, developmental, cooperative, and publication activities, this monthly publication is designed for the industry-oriented individual whose daily work involves intimate contact with science and technology-for engineers, chemists, physicists, research managers, product-development managers, and company executive's. Includes listing of all NBS papers as issued. Annual subscription: Domestic, $\$ 3.00 ; \$ 1.00$ additional for foreign mailing.

\section{Bibliographic Subscription Services}

The following current-awareness and literaturesurvey bibliographies are issued periodically by the Burcau: Gryogenic Data Center Current Awareness Service (weekly), Liquefied Natural Gas (quarterly), Superconducting Devices and Materials (quarterly), and Electromagnetic Metrology Current Awareness Service (monthly). Available only from NBS Boulder Laboratories. Ordering and cost information may be obtained from the Program Information Office, National Bureau of Standards, Boulder, Colorado 80302 .

\section{NONPERIODICALS}

Applied Mathematics Series. Mathematical tables, manuals, and studies.

Building Science Series. Research results, test methods, and performance criteria of building matcrials, components, systems, and structures.

Handbooks. Recommended codes of engineering and industrial practice (including safety codes) developed in cooperation with interested industries, professional organizations, and regulatory bodies.

Special Publications. Proceedings of NBS conferences, bibliographies, annual reports, wall charts, pamphlets, etc.

Monographs. Major contributions to the technical literature on various subjcces related to the Bureau's scientific and technical activities.

National Standard Reference Data Series. NSRDS provides quantitative data on the physical and chcmical properties of materials, compiled from the world's literature and critically evaluated.

Product Standards. Provide requirements for sizes, types, quality, and methods for testing various industrial products. These standards are developed cooperatively with interested Government and industry groups and provide the basis for common understanding of product characteristics for both buyers and sellers. Their use is voluntary.

Technical Notes. This series consists of communications and reports (covering both other-agency and NBS-sponsored work) of limited or transitory interest.

Federal Information Processing Standards Publications. This series is the official publication within the Federal Government for information on standards adopted and promulgated under the Public Law 89-306, and Bureau of the Budget Circular A-86 entitled, Standardization of Data Elements and Codes in Data Systems.

Consumer Information Series. Practical information, based on NBS research and experiencc, covering areas of interest to the consumer. Easily understandable language and illustrations provide useful background knowledge for shopping in today's technological marketplace.

\section{CATALOGS OF NBS PUBLICATIONS}

\section{NBS Special Publication 305, Publications of} the NBS. 1966-1967. When ordering, include Catalog No. C13.10:305. Pricc $\$ 2.00$; 50 cents additional for foreign mailing.

NBS Special Publication 305, Supplement 1, Publications of the NBS, 1968-1969. When ordering, include Catalog No. C13.10:305/Suppl. 1. Price $\$ 4.50 ; \$ 1.25$ additional for foreign mailing.

NBS Special Publication 305, Supplement 2, Publications of the NBS, 1970. When ordering, include Catalog No. C13.10:305/Suppl. 2. Price $\$ 3.25 ; 85$ cents additional for foreign mailing. 
U.S. DEPARTMENT OF COMMERCE

National Bureau of Standards

Washington, D.C. 20234

POSTAGE AND FEES PAIO U.S. OEPARTMENT OF COMMERCE

OFFICIAL BUSINESS

Penalty for Private Use, $\mathbf{5 3 0 0}$
215

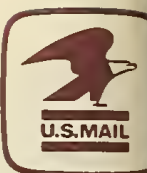

